\title{
Long term picoplankton dynamics in a warm-monomictic, tropical high altitude lake
}

\author{
Miroslav MACEK ${ }^{1,2)^{*}}$, Javier ALCOCER ${ }^{1)}$, Alfonso LUGO VÁZQUEZ ${ }^{1)}$, \\ María Elena MARTÍNEZ-PÉREZ ${ }^{1)}$, Laura PERALTA SORIANO ${ }^{1)}$ and Gloria VILACLARA FATJÓ' ${ }^{1)}$ \\ ${ }^{1)}$ National Autonomous University of Mexico, FES Iztacala, Tropical Limnology Research Project, Av. de los Barrios 1, 54090 \\ Tlalnepantla, Edo. México, Mexico \\ ${ }^{2)}$ Biology Centre AS CR, Institute of Hydrobiology, Na sádkách 7, 37005 České Budějovice, Czech Republic \\ *e-mail corresponding author:mirek@campus.iztacala.unam.mx
}

\begin{abstract}
Long term analyses of the microbial loop, centred on the picoplankton dynamics, were carried out over a five-year (1998 to 2002) period in Lake Alchichica (Puebla, Mexico), a high altitude tropical athalassohaline lake. The hydrodynamics of the lake followed a warm-monomictic pattern with mixing at a minimum temperature during the early dry season while the stratification was pronounced in the late dry season and throughout the rainy season; anoxic conditions in the hypolimnion lasted $<9$ months. The annual mean concentrations of chlorophyll-a were below $4 \mu \mathrm{g} \mathrm{L} \mathrm{L}^{-1}$ in 1998, 1999 and 2001, however, 6.1 and $5.2 \mu \mathrm{g} L^{-1}$ in 2000 and 2002, respectively. Total picoplankton, TPP, displayed a temporal pattern that followed the mixing-stratification cycle. The highest $T P P$ values (the whole water column $\geq 5 \times 10^{6}$ cells $\mathrm{mL}^{-1}$ ) were found during mixing and early stratification (January-March). The minimum numbers were present during late stratification (October-November). The maximum TPP numbers were observed within the layer 0-20 m, which corresponded to the epilimnion during the stratification period. Neither the thermocline nor the deep chlorophyll maximum showed an elevated TPP concentration. In the hypolimnion, TPP numbers were low (frequently $<1 \times 10^{6}$ cells $\mathrm{mL}^{-1}$ ) apparently as a result of the long period of anoxia. Notwithstanding autotrophic picoplankton (APP) contributed even $\geq 30 \%$ of TPP (2001 to 2002); no significant correlation was found between TPP and chlorophyll-a.
\end{abstract}

Key words: athalassohaline lake, picoplankton, bacteria, chlorophyll-a, anoxia

\section{INTRODUCTION}

During previous decades, the status of pelagic microbial assemblages in European mountain lakes (mostly dimictic) has been intensively studied (Patrick et al. 1998), namely within two European Projects: MOLAR (Mountain Lakes Research Program) and EMERGE (European Mountain lake Ecosystems: Regionalisation, diaGnostics \& socio-economic Evaluation). It was found that a significant proportion of the pelagic biomass (in terms of organic carbon) was covered by bacteria; Autotrophic picoplankton were very scarce in almost all studied mountain lakes (Straškrabová et al. 1999, 2000a, b). On the other hand comprehensive studies on high altitude tropical lakes are scarce (e.g., Macek et al. 1994). The unpolluted deep tropical lakes of Mexico (State of Puebla) are generally warm-monomictic, i.e. mixing one time per year at a minimum temperature. Compared to temperate lakes, the relation among microbe numbers and activity and the dissolved oxygen stratification at metalimnion has not been completely understood (Macek et al. 1994; Lewis 1996; Oliva et al. 2001). Due to the combination of nutrient limitation and high transparency of oligotrophic waters, a metalimnetic deep chlorophyll maximum (DCM) reflecting important primary production was observed (Abbott et al. 1984; Padisak et al. 1997;
Adame et al. 2007). However, deep tropical lakes rapidly develop an anoxic hypolimnion lasting the entire stratification period: this is the case of the deep crater lakes of the Mexican Plateau (Alcocer et al. 2000; Filonov \& Alcocer 2002).

Most of the available information describing total picoplankton (TPP) from unpolluted environments comes from temperate latitudes (e.g., Pernthaler et al. 1998; Straškrabová et al. 1999; Søndergaard 2000). It has been found that autotrophic picoplankton (APP) could form an important part of total picoplankton biomass in oligotrophic environments (Weisse 1993; Stockner 1991; Callieri 2008). Few studies have considered the picoplankton from the anoxic hypolimnion, particularly, the importance of sulphate reducing bacteria (Caldell \& Tiedje 1975; Jellison \& Melack 1993).

Generally, secondary substrates produced primary production control of the heterotrophic picoplankton (HPP) dynamics along with inorganic nutrient availability. In waters with low nutrient and carbon concentration, APP may take advantage of the competition against either HPP (Drakare 2002) or phytoplankton because they might use low concentrations of nutrients and moreover very low light intensity for their development (Vadstein 2000; Callieri et al. 2007). However, in ultraoligotrophic marine environments, bacteria could be phosphorus-controlled meanwhile APP is co-limited by phosphorus and nitrogen (Moutin et al. 2002; Zohary 
et al. 2005). A direct relationship between total chlorophyll- $a$ concentration and picoplankton numbers was formulated in early 80's (Bird \& Kalf 1984), however, it was not generally confirmed (e.g., Rao et al. 1979; Straškrabová et al. 1999, 2000a, b); particularly, sodalakes showed quite a different behaviour (Zinabu \& Taylor 1997.

The aim of the study was to unravel the picoplankton temporal and vertical dynamics in the warmmonomictic Lake Alchichica, and find out if it is related to its hydrodynamics, i.e., mixing-stratification periods and/or to the presence of its protist consumers. The originality of this investigation relies on the long-term (i.e., 5 years) follow up of picoplankton dynamics rarely published from unpolluted tropical lakes.

\section{METHODS}

\subsection{Site description}

Lake Alchichica is at $19^{\circ} 24^{\prime} \mathrm{N}, 97^{\circ} 24^{\prime} \mathrm{W}$ and 2,340 $\mathrm{m}$ above sea level. Climate is dry and temperate, with a mean annual temperature of $12.9{ }^{\circ} \mathrm{C}$, and mean annual precipitation of less than $400 \mathrm{~mm}$ (García 1988), concentrated in the ("summer") rainy season. It is a deep lake (maximum depth $62 \mathrm{~m}$, mean depth $40.9 \mathrm{~m}$ ), with a surface area of $2.3 \mathrm{~km}^{2}$ and a volume of $94,214,080 \mathrm{~m}^{3}$ (Filonov et al. 2006) of saline $\left(8.5 \mathrm{~g} \mathrm{~L}^{-1}\right)$ and alkaline (pH 9.5) water.

\subsection{Data collection}

The lake was sampled on approximately a onemonth basis for five years (1998-2002). The sampling station was at the central and deepest part of the lake. Sampling took place between 12:00 and 15:00 h (strong wind and/or rain occurred typically later).

Profiles of temperature and dissolved oxygen, D.O. (Hydrolab DS4/SVR4 Water Quality Monitoring System), photosynthetic active radiation, PAR and natural fluorescence (Biospherical Instruments PFN-300 profiler) were analysed to select discrete sampling depths. Biological samples were taken using Niskin (USA) or IHE (Czech Republic) water samplers at five (1998 and 1999 ) or at 10 depths (2000 to 2002), covering the water column from $2 \mathrm{~m}$ to 50 and $60 \mathrm{~m}$, respectively.

The samples for total picoplankton enumeration were fixed with formalin to $2 \%$ (Straškrabová et al. 1999).

\subsection{Procedures}

Throughout the study, direct numbers of total picoplankton (TPP) were evaluated in the samples concentrated onto polycarbonate membranes $(0.2 \mu \mathrm{m}$ pore-sized), DAPI-stained and mounted in immersion oil (Porter \& Feig 1980). Autotrophic picoplankton (APP) were evaluated regularly from October 2001 through to 2002. APP was concentrated onto polycarbonate membranes $(0.2 \mu \mathrm{m})$ and mounted in glycerol (to $20 \%$ ) or in immersion oil and was counted via autofluorescence (microscopes Zeiss and Leica, Germany, respectively). Optimum fluorescence provided the $\mathrm{Cy} 3$ filter-set (green excitation - and red observation-light); commonly used yellow fluorescence of APP upon AO and FITC sets (MacIsaac \& Stockner 1993; Callieri \& Stockner 2002) was too low for counting.

Chlorophyll- $a(\mathrm{Chl}-a)$ concentration was determined fluorometrically in samples filtered onto GF/F (Whatmann, USA) filters. Pigment extraction was carried out by placing the filters in $90 \%$ acetone at $4{ }^{\circ} \mathrm{C}$ overnight. Samples were analyzed using a 10AU Turner Designs Fluorometer, which was calibrated using a Turner Designs Chl- $a$ primary standard, and at each field trip with a Turner Designs Chl- $a$ secondary solid standard (Arar \& Collins, 1997). For details, see Adame et al. (2007).

\subsection{Data analysis}

All data were used to construct depth profile graphs (Surfer 6, Golden Software, USA) and to correlate a position of maximum TPP/APP with maximums of Chl- $a$ and with a temperature/dissolved oxygen maximum gradient. To describe annual dynamics, depthweighted means were used, calculated from the top 20 $\mathrm{m}$ (approximating a euphotic zone), the whole water column and the layer below $35 \mathrm{~m}$ (anoxic, except for the mixing period).

Chl- $a$ and temperature data, used to consider the relationship with TPP, were transformed using a linear interpolation between two sampling points. Non-linear regression analysis of the logarithmic transformed data of picoplankton numbers was performed using a GraphPad Software (USA) programs Prism 4 and InStat. All data were used as single points to find the best fit curve, this was done by employing a selected program-incorporated equations. One-way analysis of variance (ANOVA) and Dunnett multiple comparisons test (against a control) was used to compare the results. Akaikes Information Criteria was used to compare different curve models of the annual development (Motulsky 1999).

\section{RESULTS}

\subsection{Physical and chemical variables}

Lake Alchichica circulated at water temperatures between 14.2 and $15{ }^{\circ} \mathrm{C}$ from late December or early January through March (Fig. 1). The epilimnion was well defined from May (steep thermocline below $10 \mathrm{~m}$ ) through to October (thermocline between 25-29 m). Maximum differences between the surface and bottom temperatures $>6{ }^{\circ} \mathrm{C}$ were observed in May $(1999,2001)$; generally, a difference $>5{ }^{\circ} \mathrm{C}$ could be found from May to October. The most pronounced gradient of temperature (about $2{ }^{\circ} \mathrm{C} \mathrm{m}^{-1}$ ) was observed during late stratifi- 


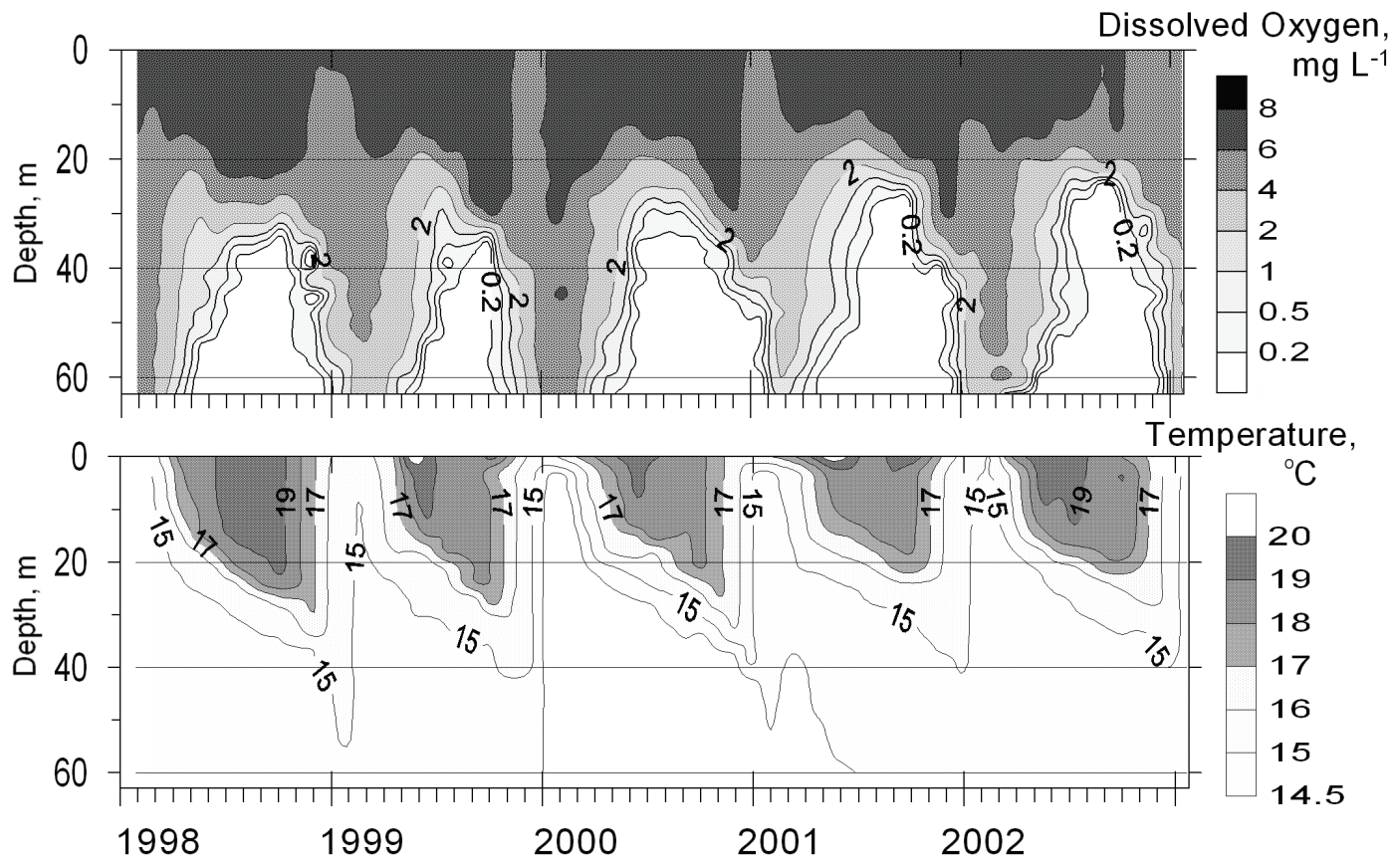

Fig. 1. Isopleths of dissolved oxygen (top panel) and isotherms (bottom panel) in Lake Alchichica.

cation, from September to November or early December. However, the annual temperature variation was lower than $5{ }^{\circ} \mathrm{C}$ for the weighted mean in the upper 20 $\mathrm{m}$, and $2{ }^{\circ} \mathrm{C}$ for the water column-mean. Bottom temperatures remained quite constant at 14.2 to $15^{\circ} \mathrm{C}$.

During periods of stratification, D.O. in the top $20 \mathrm{~m}$ was quite stable, mostly near the saturation value (Fig. 1). Over-saturation (103\%) was reached during early stratification while the lowest surface D.O. concentrations (slightly below $5 \mathrm{mg} \mathrm{L}^{-1}$ ) were observed at the start of the mixing period (late December or early January). Even during the mixing period, on days with calm wind, an oxycline could be observed, although an homogeneous D.O. distribution along the water column could rapidly develop again. During the period of pronounced stratification, D.O. decreased rapidly around the top of the thermocline reaching microaerobic $(\leq 1$ $\left.\mathrm{mg} \mathrm{L}^{-1}\right)$ or anoxic conditions $\left(\leq 0.2 \mathrm{mg} \mathrm{L}^{-1}\right.$, i.e., a membrane electrode accuracy limit) a few metres below the metalimnion. The hypolimnion was completely anoxic from May to December. In August a very steep oxycline developed which finished at anoxia and followed a similar pattern to the thermocline. An extensive description of the characteristics of annual temperature and D.O. dynamics in Lake Alchichica could be found elsewhere (Alcocer et al. 2000).

According to photosynthetically active radiation (PAR) values, the euphotic zone ranged between 15 and $20 \mathrm{~m}$ during the mixing period and reached up to $35 \mathrm{~m}$ during the stratification period (Fig. 2). During stratification, the limits of the euphotic zone was frequently found in the metalimnion.

\subsection{Chlorophyll-a}

The yearly mean Chl- $a$ concentrations were below 4 $\mu \mathrm{g} \mathrm{L}{ }^{-1}$ in 1998, 1999 and 2001, and 6.1 and $5.2 \mu \mathrm{g} \mathrm{L}^{-1}$ in 2000 and 2002, respectively (Fig. 2). The highest Chl- $a$ concentrations $\left(>10 \mu \mathrm{g} \mathrm{L}^{-1}\right)$ were reached regularly throughout the water column in January, coinciding with the lake mixing period. Phytoplankton samples from this period showed abundant diatoms (e.g., Cyclotella alchichicana (Oliva et al. 2006) and C. choctawhatcheeana).

During the cyanobacteria bloom, due to Nodularia sp., which appeared by the end of the mixing- and beginning of the stratification period (March to May), maximum Chl- $a$ concentrations were obtained at the surface layer $(20 \mathrm{~cm}$ depth) on bright and calm days. The intensity of the cyanobacteria bloom varied from year to year. During early stratification, however, the mean Chl- $a$ concentration (weighted through the upper $20 \mathrm{~m}$ ) was frequently lower than the one calculated from the entire water column. The contribution of picophytoplankton to the total Chl- $a$ was not elevated (on average, 27.7\%; Adame et al. 2007). According to in situ natural fluorescence measurements the characteristic deep chlorophyll maximum (DCM) was found during the stratification period, at the bottom of metalimnion, between 20 and $30 \mathrm{~m}$. When analysed, it was composed mainly of diatoms such as Cyclotella alchichicana and Chaetoceros elmorei. Further information regarding the pattern of phytoplankton dynamics of Lake Alchichica is presented in Oliva et al. (2001). 


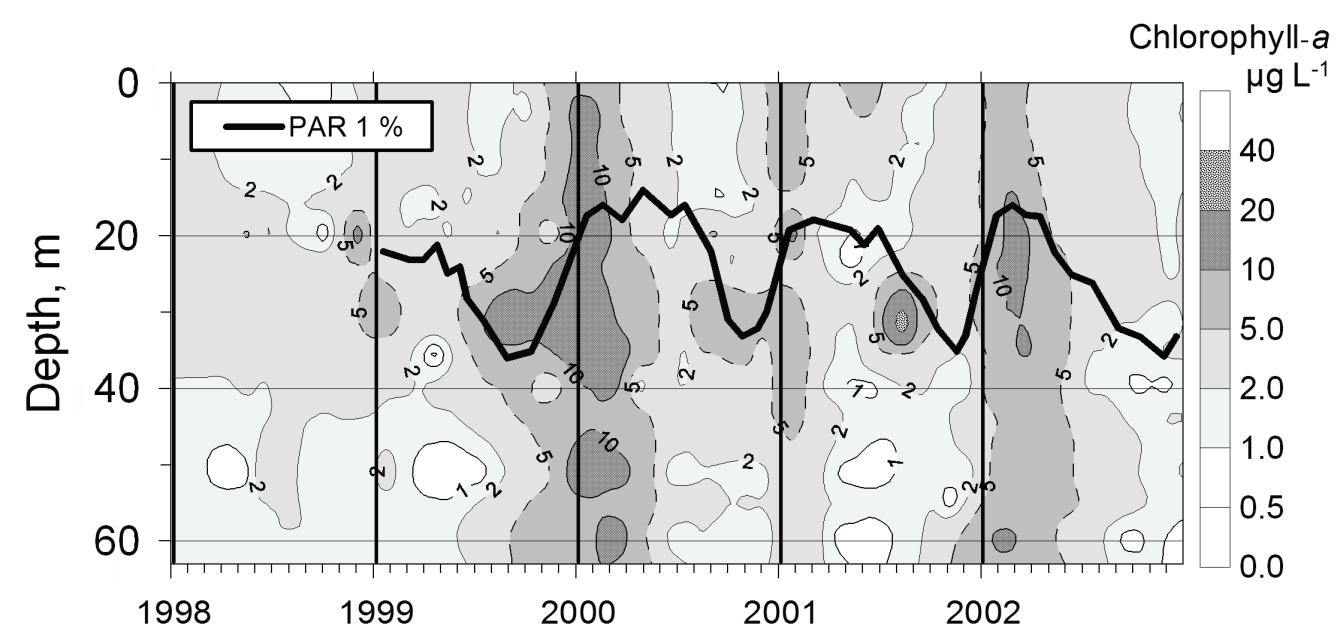

Fig. 2. Space-time distribution of chlorophyll- $a$ in the water column. The line indicates the depths with \% of surface solar radiation.

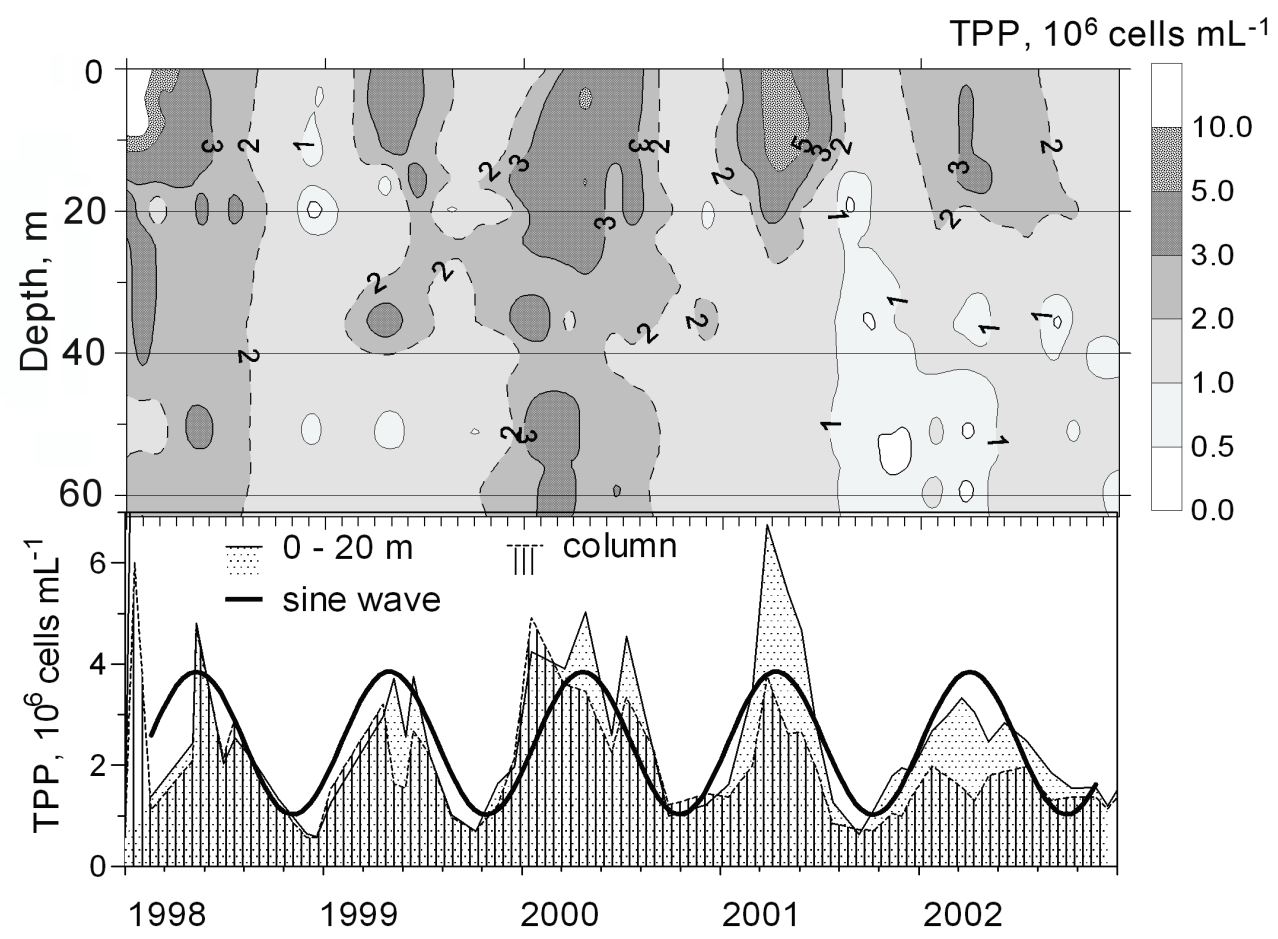

Fig. 3. Space-time distribution of total picoplankton (TPP) in the water column of Lake Alchichica (top panel). In the bottom panel: dynamics of TPP in the water column, within the top $20 \mathrm{~m}$ and its sine-wave approximation.

\subsection{Picoplankton}

The dynamics of total picoplankton in Lake Alchichica followed a regular pattern, linked to the hydrodynamics of the lake (i.e., stratification and circulation periods) (Figs 1 and 3). Along the stratification period, the depth distribution of TPP followed a regular pattern with a peak close to the bottom of the epilimnion. During the mixing period, TPP were distributed in the water column without a distinctive pattern (Fig. 3) both associated to particles and free-living.
However, the absolute maxima during this period were found in patches somewhere along the water column and appear to be associated with particulate matter resembling clay particles observed in the preparations.

The TPP seasonal pattern were quite similar across the five years. The highest mean values occurred in the year $2000\left(3.0 \times 10^{6}\right.$ cells $\left.\mathrm{mL}^{-1}\right)$ and the lowest in 2002 $\left(1.8 \times 10^{6}\right.$ cells $\left.\mathrm{mL}^{-1}\right)$, when exceptional dynamics were observed. In fact the TPP-peak observed during mixing periods was very low and similar to that formed during the stable, rainy season in July. 


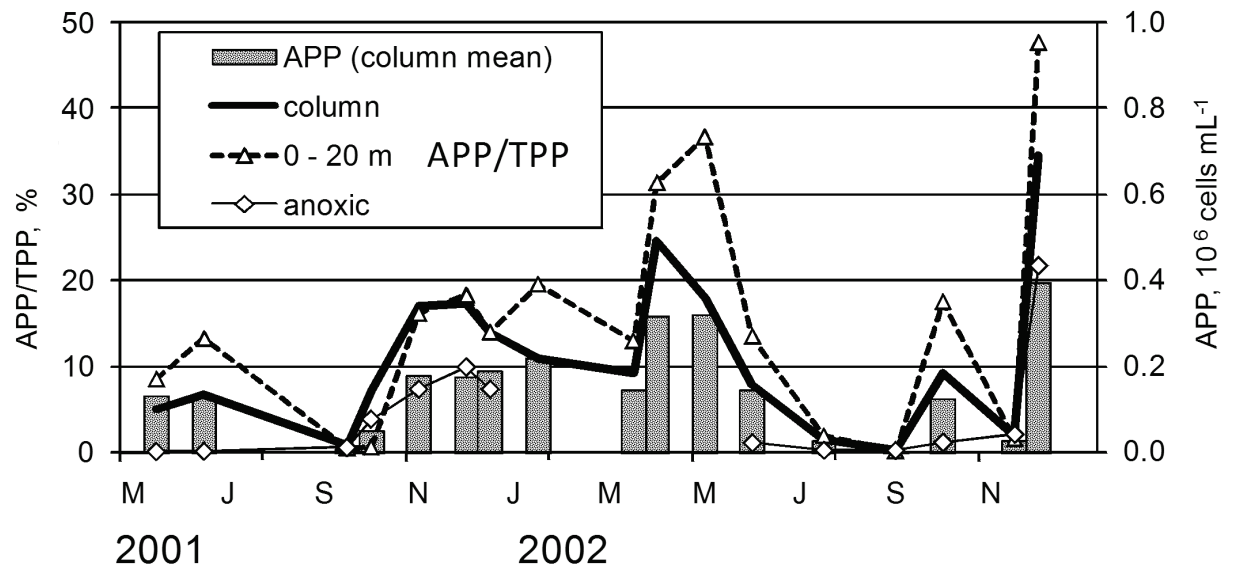

Fig. 4. Seasonal variation of autotrophic picoplankton (APP) abundance in the water column of Lake Alchichica (histograms). APP percent contribution to TPP (\%) in the water column, in the top $20 \mathrm{~m}$, and below $35 \mathrm{~m}$ layers.

The depth-weighted means of TPP of the whole water column (Fig. 3) reached the annual maximum during the mixing period between January and April $\left(1.98\right.$ to $6.9 \times 10^{6}$ cells $\left.\mathrm{mL}^{-1}\right)$ but varied from year to year. Along with stratification, TPP decreased regularly, even following filamentous cyanobacteria peaks. TPP reached the minimum between October and December along with the weakening of the thermocline, decreasing from 0.59 to $1.3 \times 10^{6}$ cells $\mathrm{mL}^{-1}$.

The APP numbers peaked $\left(1 \times 10^{6}\right.$ cells $\left.\mathrm{mL}^{-1}\right)$ just at the onset of the stratification period (Fig. 4). In 2001 and 2002, the minimum APP numbers were observed during pronounced stratification (September-October) but increased when the metalimnion weakened by the end of the year and the mixed layer became thicker. A sharp APP increase was observed just after the complete mixing of the water column in 2001.

In the top $20 \mathrm{~m}$ (Fig. 3), TPP means increased during stratification development (March to May) reaching a maximum of $6.7 \times 10^{6}$ cells $\mathrm{mL}^{-1}$. APP maximums up to $1.4 \times 10^{6}$ cells $\mathrm{mL}^{-1}$ were observed during the mixing period in the upper $10 \mathrm{~m}$, and throughout the top $20 \mathrm{~m}$ epilimnion in the early stratification period (maximum in April). Additionally, local peaks of APP were found between 10 and $20 \mathrm{~m}$, i.e., in the layer of oxygen depletion (e.g., $15 \mathrm{~m}$ in March 2002).

TPP numbers in the hypolimnion showed no pattern, which could be related to seasonality. Due to the large volume of the layer which is below $35 \mathrm{~m}$ (data not shown), the weighted mean TPP numbers were close to those of the water column mean (five year mean: $1.6 \times 10^{6}$ cells $\left.\mathrm{mL}^{-1}\right)$. During stratification, an anoxic hypolimnion was included there. The $60 \mathrm{~m}$ samples, the deepest, gave repeatedly higher numbers. Hypolimnetic minima $\left(0.24\right.$ to $1.0 \times 10^{6}$ cells $\left.\mathrm{mL}^{-1}\right)$ was found at the end of the stratification period (November-December) and/or in the early stages of the stratification (May).

TPP includes autotrophic picoplankton (APP) which have been analysed since March 2001 (Fig. 4). According to the observed autofluorescence pattern (comparing
Cy3, AO/FITC and Chl- $a$ filter sets), APP were composed by unicellular (frequently in doublets) and colonial picocyanobacteria and both morphotypes were counted. We did not confirm if the cells, single and colonial, were of the same species. Both phycoerythrin and phycocyanin picocyanobacteria were observed, and cells with brighter fluorescence were found below $1 \%$ PAR limit. Picoeukaryotes were below a detection limit (i.e., $<10^{3}$ cells $\mathrm{mL}^{-1}$ ). According to different reports, the single-cell Synechococcus nidulans and Synechocystis $\mathrm{sp}$., and the colony-forming Cyanodictyon planctonicum, Epigloesphaera glebulenta, Lemmermanniella flexa and Eucapsis cf. starmachii dominated APP in Lake Alchichica (Tavera \& Komárek 1996; Oliva et al. 2001; Komárek \& Komárková-Legnerová 2002; Rosiles-González 2005). However, according to recent findings, the majority of picophytoplankton should be composed of Aphanotece -type cells (Jezberová, personal communication).

APP numbers below the oxycline, dropped drastically; however, during the stratification period, APP increased again $\left(\geq 10^{4}\right.$ cells $\left.\mathrm{mL}^{-1}\right)$ at $60 \mathrm{~m}$. APP were also found near the bottom: exceeding $10^{4}$ cells $\mathrm{mL}^{-1}$ during the mixing and $10^{3}$ cells $\mathrm{mL}^{-1}$ during the stratification.

\section{DISCUSSION}

\subsection{The lake stratification}

The hydrodynamics (mixing-stratification; see Fig. 1) of Lake Alchichica followed a warm-monomictic pattern (c.f., Alcocer et al. 2000), commonly observed in deep tropical lakes (Lewis 1996). It means that the lake was mixed at a minimum temperature (coinciding with the early dry season), while stratification was pronounced at warm temperatures (coinciding with the late dry season), throughout the rainy season, with the maximum superficial temperature over $20^{\circ} \mathrm{C}$. However, the differences in temperature throughout the water column were small (maximum differences between the sur- 
Tab. 1. Epilimnetic and hypolimnetic dissolved inorganic nutrient concentrations \pm SD in Lake Alchichica from 1999 to 2002 (ammonium, N-NH 3 and nitrate, N$\mathrm{NO}_{3}{ }^{-}$nitrogen: dissolved reactive phosphorus, DRP, silica, $\mathrm{Si}-\mathrm{SiO}_{2}$ ); modified from Sánchez-Silva (2005).

\begin{tabular}{|c|c|c|c|c|}
\hline \multirow[t]{2}{*}{ Nutrient } & \multirow[t]{2}{*}{ Mixing period } & \multicolumn{3}{|c|}{$\begin{array}{l}\text { Stratification period } \\
\text { epilimnion/hypolimnion }\end{array}$} \\
\hline & & Early & Established & Late \\
\hline $\mathrm{N}-\mathrm{NH}_{3}\left(\mu \mathrm{mol} \mathrm{L}{ }^{-1}\right)$ & $6.3 \pm 2.9$ & $\begin{array}{l}2.2 \pm 1.6 \\
9.0 \pm 6.8\end{array}$ & $\begin{array}{c}2.3 \pm 2.6 \\
15.6 \pm 8.7\end{array}$ & $\begin{aligned} 2.9 & \pm 2.2 \\
26.4 & \pm 11.2\end{aligned}$ \\
\hline $\mathrm{N}^{-\mathrm{NO}_{3}}{ }^{-}\left(\mu \mathrm{mol} \mathrm{L}{ }^{-1}\right)$ & $0.8 \pm 0.2$ & $\begin{array}{l}0.3 \pm 0.6 \\
1.1 \pm 1.0\end{array}$ & $\begin{array}{l}0.3 \pm 0.3 \\
0.3 \pm 0.2\end{array}$ & $\begin{array}{l}0.4 \pm 0.3 \\
0.2 \pm 0.2\end{array}$ \\
\hline $\mathrm{DRP}\left(\mu \mathrm{mol} \mathrm{L}{ }^{-1}\right)$ & $0.06 \pm 0.02$ & $\begin{array}{l}0.3 \pm 0.2 \\
1.1 \pm 0.5\end{array}$ & $\begin{array}{l}0.3 \pm 0.1 \\
1.6 \pm 0.7\end{array}$ & $\begin{array}{l}0.3 \pm 0.1 \\
2.3 \pm 1.1\end{array}$ \\
\hline $\mathrm{Si}-\mathrm{SiO}_{2}\left(\mu \mathrm{mol} \mathrm{L}{ }^{-1}\right)$ & $2.2 \pm 2.5$ & $\begin{array}{c}3.2 \pm 2.1 \\
12.1 \pm 8.1\end{array}$ & $\begin{array}{l}4.6 \pm 2.1 \\
14.8 \pm 7.1\end{array}$ & $\begin{array}{c}4.3 \pm 1.7 \\
20.3 \pm 8.7\end{array}$ \\
\hline
\end{tabular}

face and bottom temperature $>5{ }^{\circ} \mathrm{C}$ could be found from May to October). A temperature gradient of over $0.5^{\circ} \mathrm{C}$ $\mathrm{m}^{-1}$ (observed from March-April to November or December) was enough to maintain a distinctive metalimnion (compare, Alcocer et al. 2000). Similar warm-monomictic behaviour was found both in the region (e.g., Lake Atexcac, Puebla, Mexico; Macek et al. 1994) and at other latitudes and/or altitudes, e.g., in the Italian crater Lake Martignano (Margaritora et al. 2003) with similar morphometric characteristics.

At the surface layer, D.O. near-to saturated concentration was common. The D.O. over-saturation (103\%) was found at the early stratification period associated to the filamentous cyanobacteria bloom (cfr., Oliva et al. 2001). Extended hypolimnetic anoxia are quite common in tropical lakes: in this sense Lake Alchichica was not an exception. The relatively high hypolimnetic temperature $\left(>14^{\circ} \mathrm{C}\right)$ and salinity, reduce the oxygen-holding capacity of water. The microbial activity in such conditions leads to the removal of D.O. Due to the large volume of anoxic hypolimnetic water before mixing, low values of D.O. could be expected in the whole water column at the start up, however, the lowest D.O. concentration observed in the surface was slightly below $5 \mathrm{mg} \mathrm{L}^{-1}$. The lake D.O. deficit, i.e. redox potential, never reached values typical for strict anaerobic processes.

Maximum gradients of oxygen depletion coincided with the maximum gradient of temperature, generally, during the late stratification period (from $\mathrm{Au}$ gust/September). On the other hand, until March-April, including the period after mixing (from January-February), a pronounced gradient of D.O. was observed without a clear relation to an existence and/or the position of metalimnion. Apparently, even with an homogeneous temperature profile, the lake was not permanently mixed and biological processes produced such oxygen depletion.

\subsection{Picoplankton annual and spatial development}

According to annual mean chlorophyll- $a$ concentration throughout the water column and the nutrient con- centrations (Tab. 1; Sánchez-Silva 2004), Lake Alchichica can be considered as oligo- to mesotrophic. The TPP numbers (about $2.0 \times 10^{6}$ and $2.7 \times 10^{6}$ cells $\mathrm{mL}^{-1}$ in the whole water column and in the top $20 \mathrm{~m}$, respectively) were higher than those observed in oligotrophic lakes (Straškrabová et al. 1999, 2000 a, b), and among the range reported from mesotrophic to eutrophic-temperate water bodies both dimictic (Šimek et al. 1995) and monomictic (Gurung \& Urabe 1999).

The annual fluctuation of the mean TPP numbers in the water column, particularly in the top $20 \mathrm{~m}$, showed a periodicity related to the lake's hydrodynamics. With all the datasets, it was possible to model the seasonal TPP oscillation using a third order polynomial model starting in October, when the TPP reached minimum numbers, before late stratification. In the top $20 \mathrm{~m}, R^{2}$ varied from 0.690 to 0.907 in 2001 and 2002, respectively, while for the water column weighted average, $R^{2}$ from 0.485 to 0.826 in 2002 and 2001, respectively. The model did not apply for the repeatedly observed, one sampling-date TPP depletion (see Fig. 3), occurring within May-July and coinciding with the start of the rainy season (early stratification). For the statistical treatment of such a depletion without a well defined position within the Julian date-axis we have not got a sufficiently robust data set.

Throughout the whole study, we were able to model a sine wave equation using the mean concentration and the standard deviation as a baseline and an amplitude first approximation, respectively. The estimated model (Fig. 3) applied in the epilimnion $\left(R^{2}=0.570\right.$; baseline and amplitude $2.4 \times 10^{6}$ and $1.4 \times 10^{6}$ cells $\mathrm{mL}^{-1}$, respectively) was not significant for the whole water column means. On the other hand, in the freshwater tropical reservoirs it was observed that the periodicity in TPP development is quite insignificant during dry/wet season (Peduzzi \& Schiemer 2004).

The last studied year (2002) showed different TPP dynamics compared with the previous four years. It has been shown that El Niño/La Niña phenomena influenced Alchichica (Alcocer \& Lugo 2003) during the study period, and the 2002 TPP dynamics seems to be 
related to a common inter-annual variation during such periods.

Comparing common APP composition (Callieri \& Stockner 2002; Wakabayashi \& Satoshi 2004), picocyanobacteria from Alchichica showed different fluorescence behaviour: Prevailing red- orange fluorescence was excited upon $\mathrm{Cy} 3$ filter set, while UV/blue excitation gave very low signal; yellow-orange fluorescence excited with green light was present but at low levels. Intensity of fluorescence signal varied along with the sampled layer depth: low signal coinciding with low numbers of APP found, e.g., in August 2001, might reflect APP damage by UV radiation (Bertoni \& Callieri 1999; Medina-Sánchez et al. 2002). On the other hand, APP observed around the limit of the euphotic zone were much brighter, which could be connected with changes of photosynthetic pigment concentrations in low-light conditions (Callieri \& Stockner 2002). Chl- $a$ signal of the APP fraction was very low, in agreement with the findings of Adame et al. (2007) . APP biomass estimation based only on Chl- $a$ could underestimate the true value of this fraction, which is characterised by the presence of cyanobacteria with phycobiliproteins and other pigments.

\subsection{Picoplankton relation to other parameters}

We could not relate the depth distribution pattern of TPP directly to the temperature gradient pattern. The metalimnion was not found to be the layer with maximum TPP numbers as expected due to the potential decay of primary production there (e.g., Šimek et al. 1995). In Lake Alchichica, phytoplankton could be active in a metalimnion still having $\leq 1 \%$ of the surface PAR. The light limit level coincided frequently with the upper limit of hypolimnion but it was above the DCM during the late stratification. However, maximum TPP was frequently found above the metalimnion.

The absolute TPP maximums of $10^{7}$ cells $\mathrm{mL}^{-1}$, found during the mixing period, could be related to the microscopically observed inorganic - seemingly allochthonous seston, which was found in distinct layers not related to the column stratification, and settling along with bacteria. Such events occurred during the dry season (particularly during February and March) with a windy climate but also could be observed after the first precipitations, which transported fine particulate material (particles of a soil which is based on a volcanic ash) from the crater surroundings. On two occasions, TPP numbers were analysed for 3 consecutive days, following abundant rainfall: a continuous sinking of the TPPrich layer was observed (data not shown). Regarding TPP numbers from DAPI, estimates do not highlight heterogeneity of bacterial community (Søndergaard 2000), it was impossible to prove directly, the origin of maximum TPP. Equally, pronounced peaks of TPP in the water column of constant temperature, sometimes along with a local D.O. depletion, might be explained on the same basis.

On the other hand, no TPP response was observed after an extraordinary large rainfall event in the end of the rainy season on October 1999, which was limnologically described (Alcocer \& Filonov 2007). A single day event delivered $1.8 \times 10^{6} \mathrm{~m}^{3}$ of water to the basin, raising the lake's water level by about $1 \mathrm{~m}$. Transparency and $\mathrm{pH}$ were slightly altered, but dissolved oxygen, nutrients and chlorophyll- $a$ concentrations were not changed apart from the upper half of the epilimnion. During the rainy season, the rapid leakage of the runoff minimized any long-term effects of the large rainfall.

We could not statistically test the TPP vs D.O. because, particularly when only 5 samples were taken, we did not analyse microbes from the exactly sampled phase-boundaries in the water column.

The production of dissolved organic carbon (DOC) by phytoplankton along with inorganic nutrients is expected to be the most important bottom-up controlling factor for bacterioplankton. However, this overwhelming control could be modulated by predators (e.g., zooplankton) particularly in more oligotrophic environments (e.g., Šimek et al. 1995; Gasol et al. 2002). In Alchichica, maximum phytoplankton biomass was found during the mixing period (expressed as Chl- $a$, from 7 to $15 \mu \mathrm{g} \mathrm{L}^{-1}$ ) but it was not reflected in much higher TPP numbers, being lower than $3 \times 10^{6}$ cells $\mathrm{mL}^{-1}$ in the upper $20 \mathrm{~m}$ layer (approximating a euphotic zone). To explain the phenomenon, we are lacking primary production parameters.

The peaks of TPP were apparently shifted after the Chl- $a$ peaks in the plots (compare, Figs 2 and 3) but no significant relationship was found between TPP mean numbers and Chl- $a$ either using instantaneous data or the consecutive sampling averages (geometrical average was applied for TPP). Additionally, we tried to correlate TPP numbers to 2-weeks-preceding, linear-interpolated data of Chl- $a$. Within the stratification period, a significant correlation between TPP and Chl- $a$ was found (Fig. 5 ) in the $0-20 \mathrm{~m}$ layer (Pearson $r=0.455,{ }^{* *}$ ). An inverse, however, weaker correlation was found (Pearson $r=-0.372, *)$ when the data from the whole water column were analysed.

A competition between APP and TPP (e.g., Drakare 2002) could explain a drop of TPP observed in AprilMay 2002, which coincided with maximum of APP (Fig. 4). During this period, APP contributed 31 to $37 \%$ of the TPP in the epilimnion and from 18 to $24 \%$ throughout the water column, meanwhile, another peak of APP related to the fall in TPP numbers was observed before the mixing start up in December 2002, when APP formed 48 and $34 \%$ in the top $20 \mathrm{~m}$ and in the water column, respectively. Decreasing TPP numbers were accompanied with an increased contribution of APP to TPP. It could be explained by the availability of 

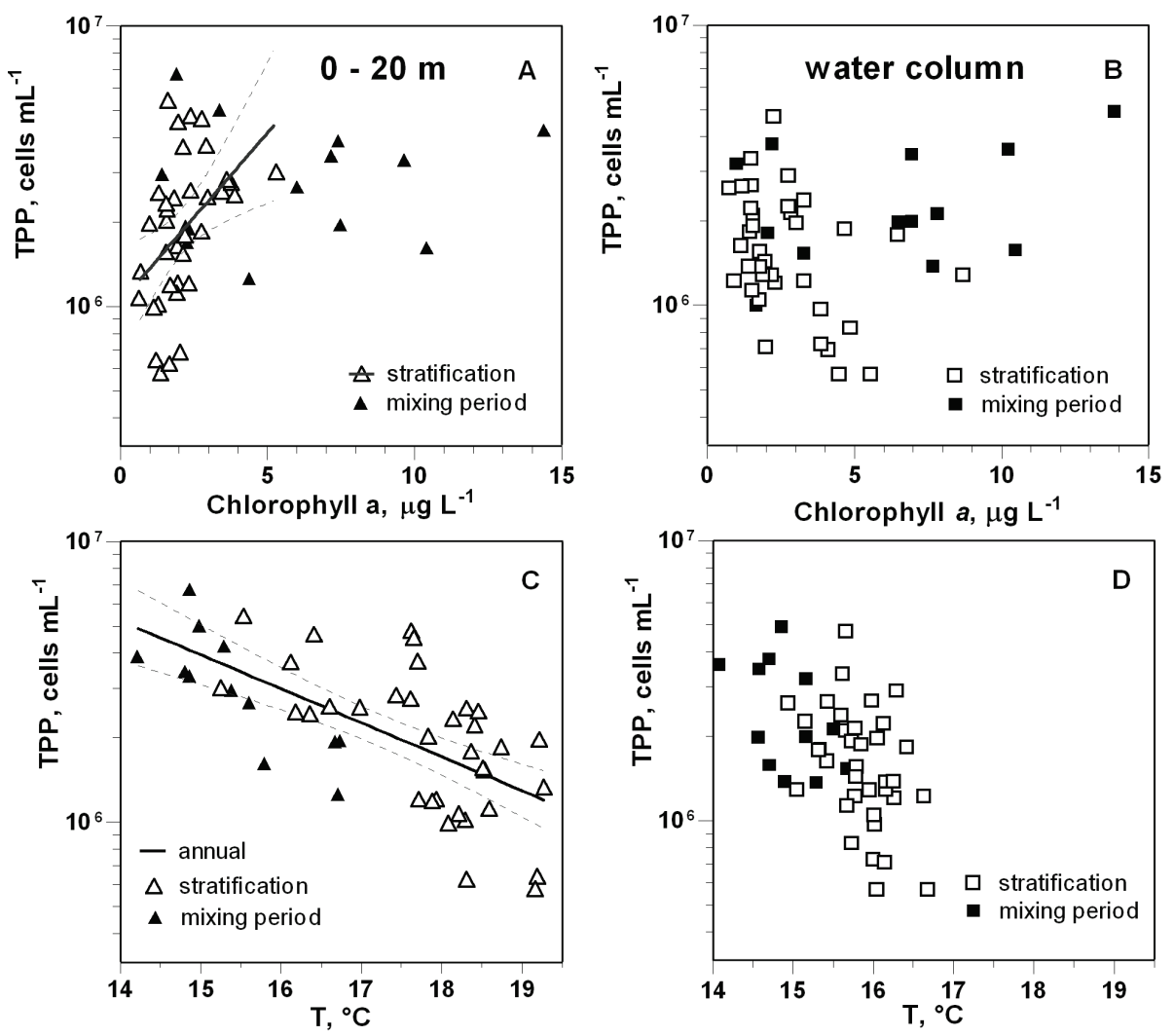

Fig. 5. Total picoplankton numbers related to chlorophyll- $a$ concentration $(\mathbf{A}, \mathbf{B})$ and temperature $(\mathbf{C}, \mathbf{D})$ in the top $20 \mathrm{~m}$ layer $(\mathbf{A}, \mathbf{C})$ and the whole water column $(\mathbf{B}, \mathbf{D})$.

nutrients (Tab. 1), upon which bacteria and APP (both included in TPP) compete in the epilimnion, as far as bacteria could have become dependent upon secondary substrates produced by phytoplankton. Upon such conditions, cyanobacteria could compete for phosphorous and could be, therefore, able to reach higher numbers relative to bacteria in waters with high P:DOC ratio (cf., (Drakare 2002). Such behaviour might be expected at the mixing start up period (December-January) when nutrient concentrations were higher than the annual average.

In an ultraoligotrophic marine environment it was recently shown that picocyanobacteria were both $\mathrm{N}$ and P co-limited while bacteria were only P limited (Zohary et al. 2005). Also in Alchichica, in the end of the mixing and beginning of the stratification periods, TPP development became seemingly nitrogen-limited; nitrogen fixing Nodularia sp. blooms appeared in the same period (compare, Oliva et al. 2001; Falcón et al. 2002). APP number-increase at the end of such blooms in surface waters could be explained as a result of succession / competition with these filamentous cyanobacteria (Callieri \& Stockner 2002). Upon exhausted nutrients and possible UV inhibition in a high altitude lake (Bertoni \& Callieri 1999; Medina-Sánchez et al. 2002), the cyanobacteria rapidly died and settled down without an apparent effect on TPP development. Also Escobar et al. (1999) showed that particulate biogenic carbon originated from Nodularia sp. in Alchichica, was not transferred within the pelagic system.

Contrary to marine systems, DOC in the lake could be allochthonous (i.e., of terrestrial origin), imported from the catchment area. On the other hand, bacteria development in temperate clear water lakes was shown to depend more on the primary production than on direct utilization of an allochthonous organic carbon that is typical for a humic lakes (Jansson et al. 2000). However, such allochthonous carbon could be important in the semi desert lake Alchichica at the end of the dry period, when first abundant precipitations might leach the surrounding area where goats graze throughout the year; also fine soil/volcanic-ash particles were apparently transported into the lake. Moreover, during mixing, the $1 \%$ PAR depth was the lowest, which could decrease the primary production. Even though it was shown that settling seston concentrations were not directly related to Chl- $a$, APP and TPP after the Lake Maggiore flooding (Bertoni et al. 2004), high TPP could be related to the seston input to an oligotrophic lake (Straškrabová et al. 1999). Then, an allochthonous origin of some TPP maxima in Alchichica could be accepted, although not proven yet.

Besides nutrient limitation, water temperature may control the TPP growth (e.g., Gurung \& Urabe 1999). Also in this case, we use an interpolation of temperature preceding two weeks of the sampling date. Significant 
negative correlations were found both in the upper 20 m layer (Fig. 5 C, $r=0.645, * * * ; 0.411, * *$ and -0.668 , *** during the stratification, mixing period, and throughout the year, respectively) and throughout the water column (Fig. $5 \mathrm{D}, r=-0.529, * * *$ ). It reflects the fact that maximum TPP numbers were observed during mixing periods and during the early stratification, which coincided with the lowest mean water temperatures but also with dry and windy seasons in the region. We might suggest that the correlation is fictitious and that the key factor for the highest TPP numbers during the season is a nutrient balance.

\section{CONCLUSIONS}

In an oligo-mesotrophic, warm monomictic, tropical high altitude lake, picoplankton annual development was found to be periodical with well defined spatial position of the peaks within the water column. TPP followed roughly preceding Chl- $a$ peaks, however, many discrepancies were found looking for a correlation. Neither filamentous cyanobacteria, Nodularia sp. occasional peaks or the deep chlorophyll maximum position, were reflected in elevated TPP numbers.

The maximum TPP peaks during the mixing period coinciding with dry season were not explained; allochthonous origin of them was speculated because of very high TPP number $5 \times 10^{6}$ cells $\mathrm{mL}^{-1}$. It was found that APP could form a very important part of TPP, particularly during the period of low Chl- $a$ concentration, apparently competing for nutrients.

\section{ACKNOWLEDGEMENTS}

Research was partly granted to M. Macek as the grant of Ministry of Education, Youth and Sports of the Czech Republic ME .296, KONTAKT, UNAM DGPA/PAPIIT grant IN208502, internal FES UNAM grant PAPCA and to J. Alcocer as CONACYT grants 34893-T and 41167. The research would have been impossible without the work of sampling team composed from UNAM colleagues and students; we thank in particular to M.Sc. Luis A. Oseguera Pérez. Last but not least we appreciate extremely helpful comments of $\mathrm{Ph} \mathrm{D}$ Callieri and unknown reviewers.

\section{REFERENCES}

Abbott, M.R., K.L. Denman, T.M. Powell, P.J. Richerson, R.C. Richards \& C.R. Goldman. 1984. Mixing and the dynamics of the deep chlorophyll maximum in Lake Tahoe. Limnol. Oceanogr., 29: 862-878.

Adame, M.F., J. Alcocer \& E. Escobar E. 2007. Size-fractionated phytoplankton biomass and its implications for the dynamics of an oligotrophic tropical lake. Freshwat. Biol., doi:10.1111/j.1365-2427.2007.01864.x .

Alcocer, J., A. Lugo, E. Escobar, M.R. Sánchez \& G. Vilaclara. 2000. Water column stratification and its implications in the tropical warm monomictic lake Alchichica, Puebla, Mexico. Verh. Internat. Ver. Theor. Angew. Limnol., 27: 3166-3169.
Alcocer, J. \& A. Lugo. 2003. Effects of El Niño on the dynamics of Alchichica, central Mexico. Geofis. Int., 42: 523-528.

Alcocer, J. \& A.E. Filonov. 2007. A note on the effects of an individual large rainfall event on saline Lake Alchichica, Mexico. Environ. Geol., doi: 10.1007/s00254-007-0690-1.

Arar, E.J.\& G.B. Collins. 1997. Method 445.0. In vitro determination of chlorophyll- $a$ and pheophytin a in marine and freshwater algae by fluorescence. Environmental Protection Agency, Cincinnati, U.S.

Bertoni, R. \& C. Callieri C. 1999. Effects of UVB radiation of freshwater autotrophic and heterotrophic picoplankton in a subalpine lake. J. Plankton. Res., 21: 1373-1388.

Bertoni, R., R. Piscia \& C. Callieri. 2004. Horizontal heterogeneity of seston organic carbon and picoplankton in the euphotic zone of Lago Maggiore, Northern Italy. $J$. Limnol., 63: 244-249.

Bird, D.F. \& J. Kalff. 1984. Empirical relationships between bacterial abundance and chlorophyll concentration in fresh and marine waters. Can. J. Fish. Aquat. Sci., 41: 10151023.

Caldell, D.E. \& J.M. Tiedje. 1975. The structure of anaerobic bacterial communities in the hypolimnion of several Michigan lakes. Can. J. Microbiol., 21: 377-385.

Callieri C. 2008. Picophytoplankton in freshwater ecosystems: the importance of small-sized phototrophs. Freshwater Reviews, 1, doi: 10.1608/FRJ-1.1.1

Callieri, C., B. Modenutti, C. Queimaliños, R. Bertoni \& E. Balseiro. 2007. Production and biomass of picophytoplankton and larger autotrophs in Andean ultraoligotrophic lakes: differences in light harvesting efficiency in deep layers. Aquatic Ecology, 41: 511-523

Callieri C. \& J.G. Stockner. 2002. Freshwater autotrophic picoplankton: a review. J. Limnol., 61: 1-14.

Drakare, S. 2002. Competition between picoplanktonic cyanobacteria and heterotrophic bacteria along crossed gradients of glucose and phosphate. Microb. Ecol., 44: 327-335.

Escobar, E., J. Alcocer, E. Cienfuegos \& P. Morales. 1999. Carbon stable isotopes ratios of pelagic and littoral communities in Alchichica crater-lake, Mexico. Int. J. Salt Lake Res., 7: 345-355.

Falcón, L.I., E. Escobar-Briones \& D. Romero. 2002. Nitrogen fixation patterns displayed by cyanobacterial consortia in Alchichica crater-lake, Mexico. In Alcocer, J. \& S.S.S. Sarma (Ed.), Advances in Mexican Limnology: Basic and Applied Aspects. Hydrobiologia, 467: 71-78.

Filonov, A.E. \& J. Alcocer. 2002. Internal waves in a tropical crater-lake: Alchichica, Central Mexico. Verh. Internat. Ver. Theor. Angew. Limnol., 28: 1857-1860.

Filonov, A., I. Tereshchenko \& J. Alcocer. 2006. Dynamic response to mountain breeze circulation in Alchichica, a crater lake in Mexico. Geophysic. Res. Lett., 33: L07404, doi:10.1029/2006GL025901.

García E. 1988. Modificaciones al Sistema de Clasificación Climática de Köppen (Para Adaptarlo a las Condiciones de la República Mexicana). Instituto de Geografía, UNAM, Mexico.

Gasol, J.M., C. Pedros-Alió \& D. Vaqué. 2002. Regulation of bacterial assemblages in oligotrophic plankton systems: results from experimental and empirical approaches. Antonie van Leeuwenhoek, 81: 435-452.

Gurung, T.B. \& J. Urabe. 1999. Temporal and vertical difference in factors limiting growth rate of heterotrophic bacteria in Lake Biwa. Microb. Ecol., 38: 136-145.

Jansson, M., A.-K. Bergstrom, P. Blomqvist \& S. Drakare. 2000. Allochthonous organic carbon and phytoplankton / bacterioplankton production relationships in lakes. Ecology, 81: 3250-3255.

Jellison, R. \& J.M. Melack. 1993. Meromixis in hypersaline Mono Lake, California. 1.Stratification and vertical mix- 
ing during the onset, persistence, and breakdown of meromixis. Limnol. Oceanogr., 38: 1008-1019.

Komárek, J. \& J. Komárková-Legnerová. 2002. Contribution to the knowledge of planktic cyanoprokaryotes from central Mexico. Preslia, 74: 207-233.

Lewis, W.M. 1996. Tropical lakes: how latitude makes a difference. In: Schiemer F. \& B.T. Boland (Ed.), Perspectives in Tropical Limnology. SPB Academic Publishing Bv., Amsterdam 43-64.

Macek, M., G. Vilaclara \& A. Lugo. 1994. Changes in protozoan assemblage structure and activity in a stratified tropical lake. Marine Microb. Food Webs, 8: 235-249.

MacIsaac, E.A. \& J.G. Stockner. 1993. Enumeration of phototrophic picoplankton by autofluorescence microscopy. In: Kemp, P., B. Sherr, E. Sherr \& J. Cole (Ed.), Handbook of Methods in Aquatic Microbiology. Lewis Publ., Boca Raton FL, USA: 187-197.

Margaritora, F.G., M. Bazzanti, O. Ferrara, L. Mastrantuono, M. Seminara \& D. Vagaggini. 2003. Classification of the ecological status of volcanic lakes in Central Italy. $J$. Limnol., 62, Suppl. 1: 49-59.

Medina-Sánchez, J.M., M. Villar-Argaiz \& P. Carrillo. 2002. Modulation of the bacterial response to spectral solar radiation by algae and limiting nutrients. Freshwat. Biol., 47: 2191-2204.

Motulsky, H.J. 1999. Analyzing Data with GraphPad Prism. GraphPad Software Inc. San Diego U.S.

Moutin, T., T.F. Thingstad, F. Van Wambeke, D. Marie, G. Slawyk, P. Raimbault \& H. Claustre. 2002. Does competition for nanomolar phosphate supply explain the predominance of the cyanobacterium Synechococcus? Limnol. Oceanogr., 47: 1562-1567.

Oliva, M.G., A. Lugo, J. Alcocer, L. Peralta \& M.R. Sánchez. 2001. Phytoplankton dynamics in a deep, tropical, hyposaline lake. Hydrobiologia, 466: 299-306.

Oliva, M.G., A. Lugo, J. Alcocer \& E.A. Cantoral-Uriza. 2006. Cyclotella alchichicana $\mathrm{sp}$. nov. from a saline Mexican lake. Diatom Res., 21: 81-89.

Padisak, J., L. Krienitz, R. Koschel \& J. Nedoma. 1997. Deeplayer autotrophic picoplankton maximum in the oligotrophic Lake-Stechlin, Germany - Origin, activity, development and erosion. Europ. J. Phycol., 32: 403-416.

Patrick, S., R.W. Battarbee, B. Wathne \& R. Psenner. 1998. Measuring and modelling the dynamic response of remote mountain lake ecosystems to environmental change: an introduction to the MOLAR project. In: Kovar K, U. Tappeiner, N.E. Peters \& R.G. Craig (Ed.), Hydrology, Water Resources and Ecology in Headwaters. International Association of Hydrological Sciences Publ. No. 248, Wallingford, USA: IAHS Press: 403-410.

Peduzzi, P. \& F. Schiemer. 2004. Bacteria and viruses in the water column of tropical freshwater reservoirs. Environ. Microbiol., 6: 707-715.

Pernthaler, J., F.O. Glöckner, S. Unterholzner, A. Alfreider, R. Psenner \& R. Amann. 1998. Seasonal community and population dynamics of pelagic Bacteria and Archaea in a high mountain lake. Appl. Environ. Microbiol., 64: 42994306.

Porter, K.G. \& Y.S. Feig. 1980. The use of DAPI for identifying and counting aquatic microflora. Limnol. Oceanogr., 25: $943-948$.

Received: September 2008

Accepted: February 2009
Rao, R., E. Kwiatkowski \& A.A. Jurkovic. 1979. Distribution of bacteria and chlorophyll a at a nearshore station in Lake Ontario. Hydrobiologia, 66: 33-39.

Rosiles-González, G. 2005. Picoplancton autotrófico de Alchichica en comparación con el fitoplancton de talla mayor: composición, abundancia y distribución durante un cíclo de estratificación y mezcla. MS thesis, Posgrado en Ciencias del Mar y Limnología UNAM Mexico.

Sánchez-Silva, R. 2004. Dinámica vertical y temporal de los nutrimentos (N, $\mathrm{P}, \mathrm{Si}$ ) en un lago monomíctico cálido tropical: Alchichica, Puebla, México. MS thesis, Posgrado en Ciencias del Mar y Limnología, UNAM Mexico.

Šimek, K., J. Bobková, M. Macek, J. Nedoma \& R. Psenner. 1995. Ciliate grazing on picoplankton in a eutrophic reservoir during the summer phytoplankton maximum: a study at the species and community level. Limnol. Oceanogr., 40: $1077-1090$.

Søndergaard, M. 2000. Bacterioplankton: how many and how active? Verh. Internat. Ver. Theor. Angew. Limnol., 27: 859-865.

Stockner, J.G. 1991. Autotrophic picoplankton in freshwater ecosystems: the view from the summit. Int. Rev. ges. Hydrobiol., 76: 483-492.

Straškrabová V., C. Callieri, L. Cruz-Pizarro, P. Hartman, M. Macek, J. Nedoma \& K. Šimek. 1999. Investigations on microbial food webs in mountain lakes - aims and methods. In: Straškrabová, V., C. Callieri \& J. Fott (Ed.). Pelagic Food Web in Mountain Lakes. MOuntain LAkes Research Program. J. Limnol., 58: 77-87.

Straškrabová, V., J. Fott, P. Hartman, M. Macek, J. Nedoma, K. Šimek \& J. Vrba. 2000a. Pelagic food webs in low-alkalinity lakes - forested and alpine catchments. Verh. Internat. Ver. Theor. Angew. Limnol., 27: 513-516.

Straškrabová, V., J. Fott, P. Hartman, M. Macek, J. Nedoma, K. Šimek \& J. Vrba. 2000b. Structure of pelagic food webs in low-alkalinity lakes - forested and alpine catchments. Silva Gabreta, 4: 199-212.

Tavera, R. \& J. Komárek. 1996. Cyanoprokaryotes in the volcanic lake of Alchichica, Puebla State, México. Algological Studies, 83: 511-538.

Vadstein, O. 2000. Heterotrophic, planktonic bacteria and cycling of phosphorus. In: Schink, B. (Ed.), Adv. Microb. Ecol., 16: 115-167.

Wakabayashi, T. \& I. Satoshi. 2004. Seasonal variations of phototrophic picoplankton in Lake Biwa (1994-1998). Hydrobiologia, 528: 1-16.

Weisse, T. 1993. Dynamics of autotrophic picoplankton in marine and freshwater ecosystems. Adv. Microb. Ecol., 13: 327-370.

Zinabu, G.M. \& W.D. Taylor. 1997. Bacteria-chlorophyll relationships in Ethiopian lakes of varying salinity: are soda lakes different? J. Plankton Res., 19: 647-654.

Zohary, T., B. Herut, M.D. Krom, R.F.C. Mantoura, P. Pitta, S. Psarra, F. Rassoulzadegan, N. Stambler, T. Tanaka, T.F. Thingstad \& E.M.S. Woodward EMS. 2005. P-limited bacteria but $\mathrm{N}$ and $\mathrm{P}$ co-limited phytoplankton in the Eastern Mediterranean - a microcosm experiment. Deep-Sea Res., II 52: 3011-3023. 